Selcuk Journal of Agriculture and Food Sciences

http://sjafs.selcuk.edu.tr/sjafs/index

Research Article
SJAFS

(2020) 34 (1), 84-90

e-ISSN: $2458-8377$

DOI:10.15316/SJAFS.2020.199

\title{
Determination of the Relationship between NDVI and Yield by Using Remote Sensing for Silage Corn in Konya Region
}

\author{
Nurettin KAYAHAN ${ }^{1, *}$, Taner USTUNTAŞ ${ }^{2}$, Cevat AYDIN ${ }^{1}$ \\ ${ }^{1}$ Selçuk University, Faculty of Agriculture, Department of Agricultural Machineries and Tecnologies Engineering, \\ Konya, Turkey \\ ${ }^{2}$ Kocaeli University, Department of Geomatics Engineering, Kocaeli, Turkey
}

\begin{tabular}{l}
\hline ARTICLE INFO \\
\hline Article history: \\
Received date: 28.02 .2020 \\
Accepted date: 16.03 .2020 \\
\hline Edited by: \\
Osman ÖZBEK; Selçuk University, \\
Turkey \\
Reviewed by: \\
Kadir SABANCI; Karamanoğlu \\
Mehmetbey University, Turkey \\
H. Kürşat ÇELIK; Akdeniz University, \\
Turkey \\
\hline
\end{tabular}

\section{Keywords:}

Remote Sensing

NDVI

Yield estimation

Precision agriculture

\begin{abstract}
This study focuses on the yield estimation of silage corn in the province of Konya. This study was carried out in Selcuk University Sarıcalar Research and Application Farm in province of Konya. In this study, normalized difference vegetation index (NDVI) values obtained by using remote sensing tecniques were compared with yield and the availability of estimation of yield by using NDVI was determined.

In the Study, approximately $1000 \mathrm{~m}^{2}$ of silage corn planted in the field. The field is divided into plots. Different doses of nitrogen applied to different plots to obtain different yields on different plots. In this way, 5 parcels having different yields were obtained. Aerial images were taken from these plots before the flowering period, during the flowering period and after the flowering period. NDVI values were calculated from these images. Yields of plots were measured in the time of harvest.

NDVI values were compared with the yield values. The highest correlation $\left(\mathrm{R}^{2}=0.945\right)$ were found between the images obtained during the flowering period and yields. It showed that the estimation of the yield is available with image taken during this period.
\end{abstract}

\section{Introduction}

Monitoring of agricultural products during the vegetation period and pre-harvest reliable yield estimation of agricultural products are important for economies of countries in terms of planning national policy, and food security (Hayes and Decker, 1996; Wu et al., 2012; Fang and Hoogenboom, 2011; Zhao et al. 2011; Prasad et al., 2006).

Classic product monitoring and yield estimation methods are usually based on a random sampling of the land. These methods are generally laborious, time consuming and expensive (Prasad et al., 2006; Fang et al., 2008).

Remote sensing for monitoring crop growth is quick and effective method, therefore it is very important technique and valuable information source for agricultural applications. (Li and Chen 2011; Prasad et al. 2006; Hatfield and Prueger 2010; Bernardes et al. 2012).

\footnotetext{
*Corresponding author email: nkayahan@selcuk.edu.tr
}

Remote sensing techniques in agriculture is often used in areas such as yield estimation (Meroni et al., 2013; Kogan et al. 2012), the product area estimation (Fritz et al., 2008; Gallego et al., 2014), irrigation scheduling (Ahmad et al., 2009; Asher et al., 2013), and the product mapping (Delrue et al., 2013; Biradar et al., 2009). Yield estimation has an important place in remote sensing applications.

Some indexes such as NDVI (normalized difference vegetation index), SAVI (soil-adjusted vegetation index) and EVI (enhanced vegetation index), obtained from plants vegetative reflections using remote sensing is closely related to the vegetative status of the plant. The NDVI introduce by Deering (1978) is most frequently used index and often used for yield forecasting applications due to its close relationship with yield (Tucker et al., 1980).

Remote sensing data used for used for calculation of vegetation indexes (VI) can be obtained from satellites or aerial remote sensing tools. Satellite based remote sensing data using for VI have some disadvantage such us cloudiness, low resolution and high cost (Sakamoto et al., 2012). Obtaining data with spectral sensors mounted on unmanned aerial vehicles and 
similar platforms can overcome these disadvantages. In studies conducted previously unmanned aerial vehicles were used to obtain data from agricultural areas (Herwitz et al., 2004, Guillen-Climent et al., 2012, Sugiura et al., 2005).

In a study using UAV (unmanned aerial vehicles) (Berni et al., 2009), the availability of remote sensing data using unmanned aerial vehicles has been examined and it has been shown that these tools can be used easily in the imaging of agricultural areas.

Sakamoto et al. (2012) observed periodic changes in crop growth with the cheap camera system and determined that the system was effective.

Corn, an important cereal plant in the world, is also increasingly prevalent in Turkey (Ibrikci and Ulger, 2012; Bozkurt et al., 2006). In the studies conducted (Ulger et al., 1997; Gholamhoseini et al., 2013); it was observed that the corn plant showed different yield responses to the $\mathrm{N}$ fertilizer applied at different rates and the yield improved with the increasing $\mathrm{N}$ fertilizer rate.

The aim of this study is to investigate the relationship between the yield values obtained from the images taken with a spectral camera mounted on a simple kite system from corn plant plots, which obtained different yields by changing the nitrogen dose, and NDVI values.

\section{Materials and Methods}

In this study, approximately one decare was used for silage corn planting and BC-532 maize type was used for planting. A parachute type kite system is used for aerial photography. With the purpose of taking measurements from the plants in the field; an electronic caliper with $0.01 \mathrm{~mm}$ precision, a 4-volt rechargeable scales and meter with a precision of 1 gram were used. A $50 \mathrm{~m}$ tape meter was used to dimension the parcels in the field. In order to obtain remote sensing data, multispectral camera was used and computer and software were used for the processing and evaluation of data. In order to obtain remote sensing data, multispectral camera, computer and software were used for the processing and evaluation of data. RTK-GPS (Real Time Kinematic- Global Positioning System) was used for the purpose of determining the location of the parcels on the ground. Teflon plates are used as Ground Control Point (GCP).

In this study, it was aimed to obtain different yields by dividing the land where the corn cultivation is made by the parcels in order to compare the yield with the remote sensing data. Nitrogen doses, which are effective parameters on product yield, have been used to achieve this (Tunalı et al., 2012). The seeding process was carried out in the summer of 2012. To obtain different yields, $0,10,20,30,40 \mathrm{~kg} \mathrm{~N} /$ decare doses of nitrogen were used in the intended fertilizer. The experiment was set up in 3 replications according to the design of random blocks and each replicate consists of
8 rows with a distance of 0.7 meters and a length of 10 meters.

On the land to be planted, the primary soil treatment was carried out with a plow, the doubling was carried out with crowbar cultivator and a seed bed preparation was made with a gear-rotary harrow combination. Pneumatic precision sowing drill was used in the sowing process and the planting depth, row spacing and distance between rows were set at $7 \mathrm{~cm}, 25 \mathrm{~cm}$ and $0.7 \mathrm{~m}$ respectively. At the time of sowing, soil temperature was measured as $17^{\circ} \mathrm{C}$ and air temperature was measured as $30^{\circ} \mathrm{C}$. Sowing norm was set at 2.5 $\mathrm{kg} / \mathrm{da}$.

According to the applied nitrogen doses, the parcels were named N0, N10, N20, N30, and N40, respectively. Nitrogen application of $0,10,20,30,40 \mathrm{~kg} / \mathrm{da}$ in total was made to these parcels respectively. After planting, TSP (Triple Süper Fosfat) containing P of 10 $\mathrm{kg} / \mathrm{da}$ was applied to the N0 named parcel and DAP (Diammonium phosphate) fertilizer containing $4 \mathrm{~kg} /$ da $\mathrm{N}$ and $10 \mathrm{~kg} / \mathrm{da} \mathrm{P}$ was applied to the other parcels. The remainder of the nitrogen is given in urea form after the second hoeing.

7 days after sowing, plant germination began. The first anchor, the second anchor, the throat filling and weed spraying processes were applied respectively during plant development. The water was irrigated a total of 5 times, 3 times sprinkling to the second hoeing application and then the furrow irrigation.

The plants entered the flowering period 70 days after sowing and were harvested 98 days later.

\subsection{Harvesting and Plant Measurements During Har- vest}

The harvesting process was performed manually and the harvested plants for each parcel were weighed with a charged scale. The yields of the parcels were calculated by proportioning the plant weights to the areas of the harvested parcels.

During the harvesting, 20 plants were identified in each plot and the plant height, number of cobs, height of cob, stem diameter, leaf length, leaf width, plant weight, leaf weight, weight of cob and stem weight of these plants were measured. These measurements were made with meters, electronic calipers and charged scales.

\subsection{RTK-GPS measurement}

A GPS point near the work site is installed as shown in Figure 1. Coordinates of the fixed point were calculated by performing continuous GPS measurement for two hours.

As shown in Figure 2, five GCP were installed in such a way that the points would surround the parcels and the teflon plates were placed at these points. 


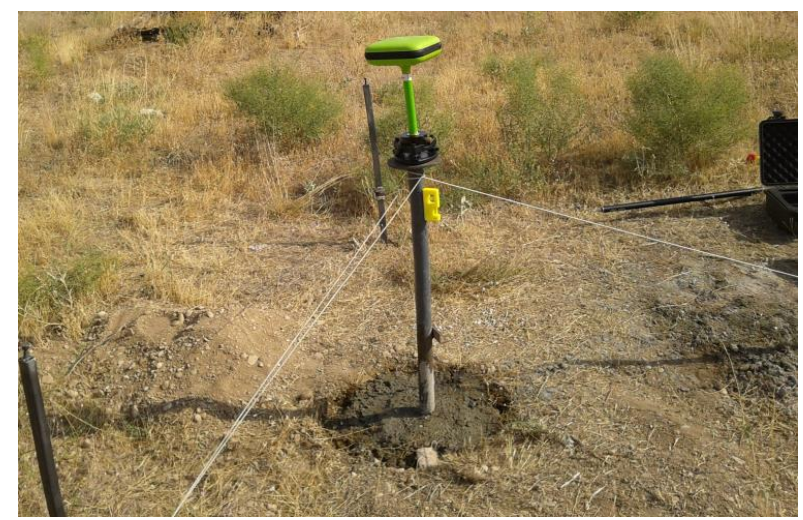

Figure 1

Fixed station established in work area

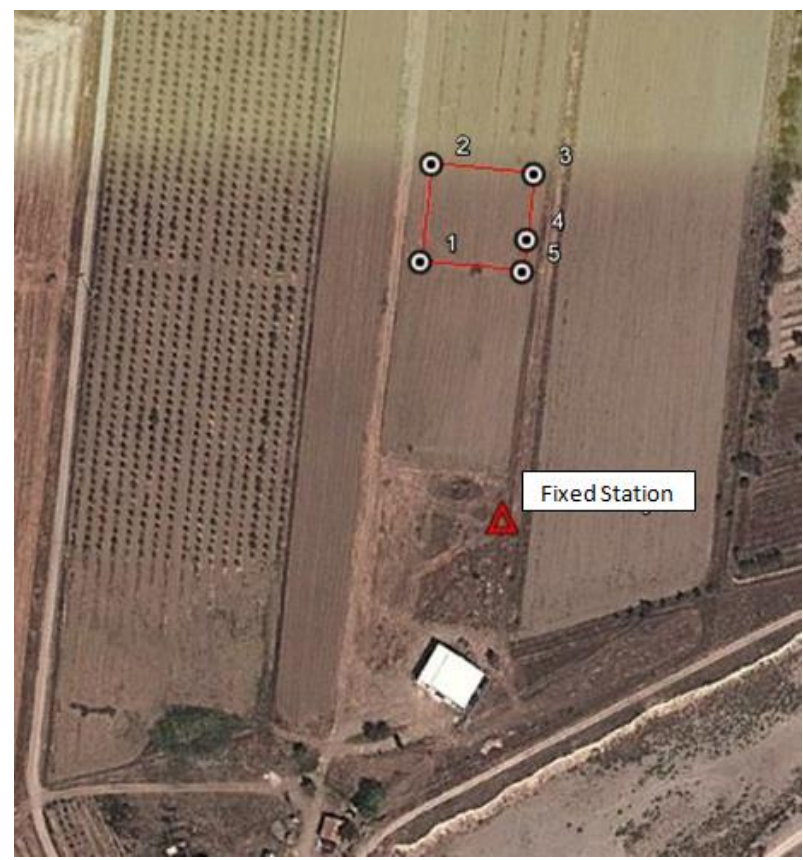

Figure 2

5 points established by RTK method in the study area

A GPS device was installed at a fixed point. With a second mobile GPS tool, 5 points were coordinated by RTK method, as shown in Figure 3, with 10 seconds waiting at each point. Coordinates are calculated in the format of geographical coordinates. All coordinates are obtained in WGS84, World Geodetic System datum. The points with new coordinates calculated in Figure 2 were displayed in the Google Earth program. The accuracy of the calculated points has also been confirmed visually.

In this study, it was aimed to calculate NDVI values with high correlation with yield through images taken from the land to compare with the yield values and to determine their usability in the yield estimation study. The images were taken in 3 different periods to be used in the NDVI calculation. Images were taken 15 days before flowering, 10 days after flowering and flowering.

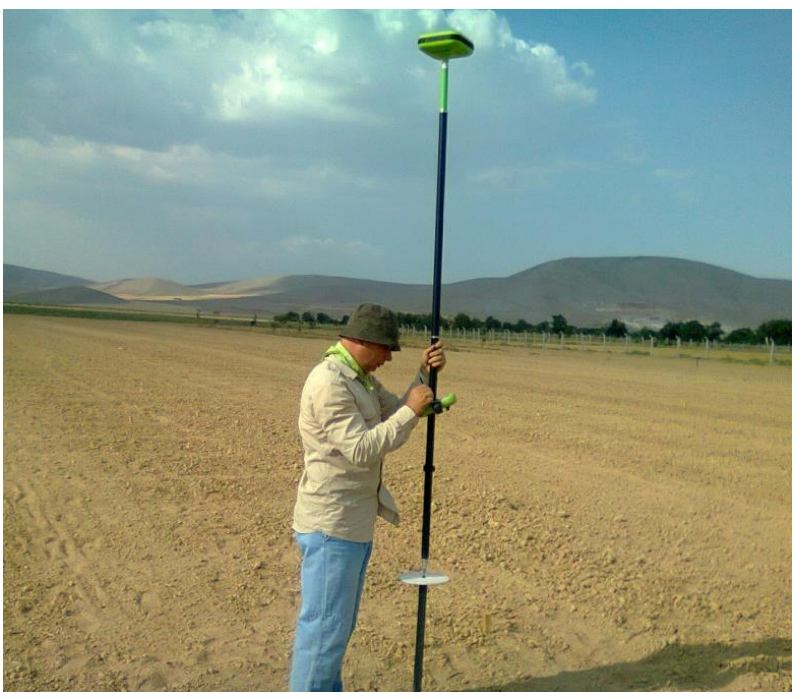

Figure 3

Coordinate points with a roving GPS tool

The newly calculated coordinates by the RTK method are given in Table 1 below.

Table 1

Coordinates of installed points in the study area

\begin{tabular}{lccc}
\hline Points & Latitude $\left({ }^{\circ}\right)$ & Longitude $\left({ }^{\circ}\right)$ & Altitude $(\mathrm{m})$ \\
\hline 1 & 32.60875 & 38.09319 & 1042.76000 \\
2 & 32.60880 & 38.09351 & 1042.66198 \\
3 & 32.60923 & 38.09348 & 1042.92102 \\
4 & 32.60920 & 38.09326 & 1042.75500 \\
5 & 32.60918 & 38.09316 & 1042.72302 \\
\hline
\end{tabular}

\subsection{Receiving and Analyzing Multi-Band Images from} Parses

The multi-band camera to capture images before shooting is set to auto mode so that it shoots every ten seconds. Days and times that the wind is in the right direction and at the proper speed to take pictures were determined by following the Website of the Meteoroloji Genel Müdürlüğü. The wind speed should be between 10-15 km / h. Once the proper wind direction and speed have been captured, the kite has been blown and has been followed for some time in the air. When the kite is stationary in the air, the camera system is connected to the kite by releasing about 50-60 m of rope. Ropes were released until the kite on the parcel. In this way the kite has been raised to an altitude of 300-500 m. During the flight, it was constantly checked whether or not the kite was on the parcels. The shooting was finished after the camera shot on the field for about two hours.

After the shooting process was finished, the most suitable land images were selected by examining the images one by one for analysis. The first selected images are positioned on the coordinate plane (Figure 4). 


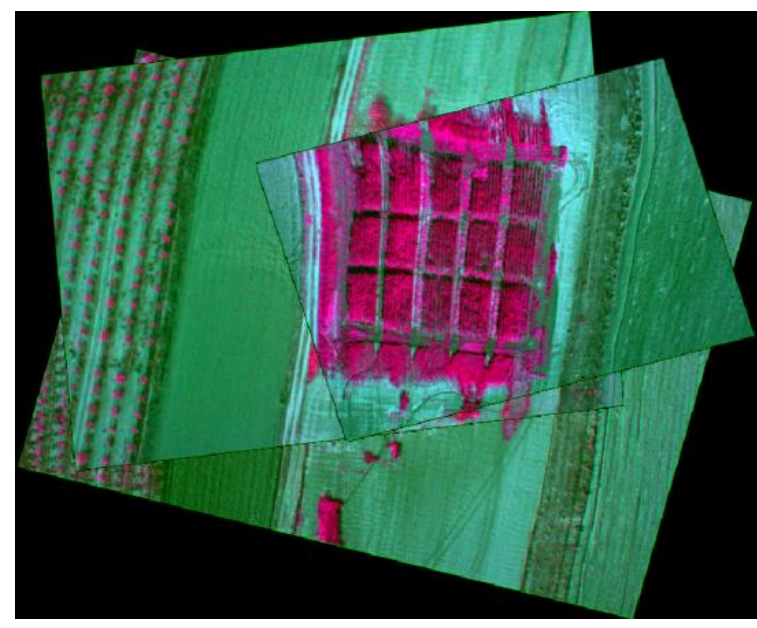

Figure 4

Coordinated picture frames

Then selected images were analyzed with Tetracam PixelWrench2 software. The images were loaded into the program, then calibrated from the 'index' menu. With the calibration process, the maximal reflections of the rays in the near infrared and red regions in the images were determined thus the program is able to calculate the reflection values from the plants by comparing them with these values. Then NDVI calculation was selected from the same menu and the mean NDVI values for each plot individually were calculated. It's one of the analyzed images is shown in Figure 5.

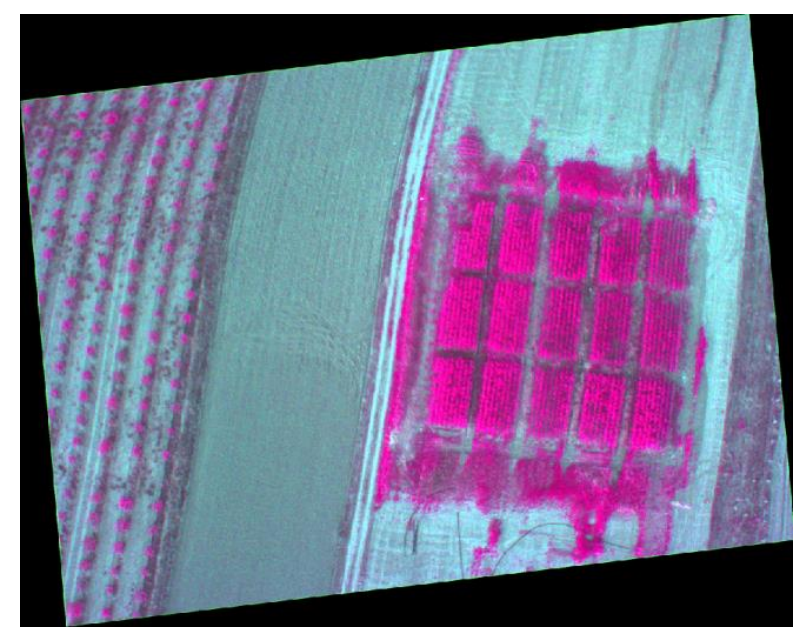

Figure 5

An analyzed image

\section{Results and Discussion}

\subsection{Plant measurements}

To obtain different yields, the parcel was named N0 $(0 \mathrm{~kg} \mathrm{~N}), \mathrm{N} 10(10 \mathrm{~kg} \mathrm{~N}), \mathrm{N} 20(20 \mathrm{~kg} \mathrm{~N}), \mathrm{N} 30(30 \mathrm{~kg} \mathrm{~N})$ and $\mathrm{N} 40(40 \mathrm{~kg} \mathrm{~N})$ according to the nitrogen application and three replications were applied. Plant height, number of cobs, height of cobs, stem diameter, leaf length, leaf width, plant weight, leaf weight, cob weight and stem weight were measured during harvesting and the average of the repeated measurements were calculated. The results of these measurements are given in Table 2.

Table 2

Measurements taken from plants during harvest in trial parcels

\begin{tabular}{lcccccccccc}
\hline Nitrogen dose & Length & $\begin{array}{c}\text { Number of } \\
\text { cob }\end{array}$ & $\begin{array}{c}\text { Height of } \\
\text { cob }\end{array}$ & $\begin{array}{c}\text { Stem } \\
\text { diameter }\end{array}$ & $\begin{array}{c}\text { Leaf } \\
\text { length }\end{array}$ & $\begin{array}{c}\text { Leaf } \\
\text { width }\end{array}$ & $\begin{array}{c}\text { Plant } \\
\text { weight }\end{array}$ & $\begin{array}{c}\text { Leaf } \\
\text { weight }\end{array}$ & $\begin{array}{c}\text { Cob } \\
\text { weight }\end{array}$ & $\begin{array}{c}\text { Stem } \\
\text { Weight }\end{array}$ \\
\hline (kg/da) & $(\mathrm{mm})$ & $($ tane $)$ & $(\mathrm{mm})$ & $(\mathrm{mm})$ & $(\mathrm{mm})$ & $(\mathrm{mm})$ & $(\mathrm{g})$ & $(\mathrm{g})$ & $(\mathrm{g})$ & $(\mathrm{g})$ \\
N0 $(0 \mathrm{~kg} \mathrm{~N} / \mathrm{da})$ & 1380,67 & 0,73 & 855,83 & 19,14 & 719,73 & 84,93 & 478,07 & 86,17 & 178,50 & 272,90 \\
N10 (10kg N/da) & 1731,67 & 1,23 & 524,29 & 20,53 & 782,67 & 122,00 & 697,93 & 115,03 & 257,23 & 325,67 \\
N20 (20kg N/da) & 1917,33 & 1,07 & 630,00 & 19,67 & 750,07 & 92,07 & 633,33 & 105,50 & 255,99 & 271,84 \\
N30(30kg N/da) & 1997,33 & 1,12 & 468,78 & 20,87 & 777,17 & 99,18 & 921,33 & 130,23 & 375,40 & 415,70 \\
N40 (40kg N/da) & 2075,24 & 1,37 & 615,61 & 21,52 & 795,11 & 101,88 & 1088,34 & 133,76 & 518,13 & 436,46 \\
\hline
\end{tabular}

The obtained yield values of all application parcels and their replicates were evaluated by performing analysis of variance. The results of the analysis of variance obtained are given in Table 3 .

When Table 4.2 was examined, it was found that the distribution of yield values obtained after harvest was statistically different between applications (P $<0.01)$, and between repeats were statistically the same $(\mathrm{P}>0.05)$.

Table 3

One-way variance analysis results according to yield values between applications and recurrences

\begin{tabular}{lccccc}
\hline $\begin{array}{l}\text { Source of } \\
\text { Variance }\end{array}$ & SS & DF & MS & $\begin{array}{c}F \\
\text { value }\end{array}$ & P value \\
\hline Application & 1.19 & 4 & 2974736 & 248.1 & $0.00^{* *}$ \\
Recurrence & 106306.6 & 2 & 53153.3 & 4.4 & 0.51 \\
Error & 95908 & 8 & 11988 & & \\
Total & 1.2 & 14 & & & \\
\hline$* * \mathrm{P}<0.01$ & & & & &
\end{tabular}

The yield values obtained from all the parcels during harvest are given in Table 4 .

Table 4

Yield values of experimental plots according to nitrogen dosing

\begin{tabular}{cc}
\hline Nitrogen dose $(\mathrm{kg} / \mathrm{da})$ & Yield $(\mathrm{kg} / \mathrm{da})$ \\
\hline N0 $(0 \mathrm{~kg} \mathrm{~N})$ & 1807 \\
N10 $(10 \mathrm{~kg} \mathrm{~N})$ & 2673,66 \\
N20 $(20 \mathrm{~kg} \mathrm{~N}$ & 3542,49 \\
N30(30kg N) & 4093,78 \\
N40 (40kg N) & 4118,425 \\
\hline
\end{tabular}

3.2. Analysis Results of Data Obtained by Remote Sensing

Images taken by remote sensing were taken at three different times: before flowering (15 days before), during flowering and after flowering (10 days after flowering). The obtained NDVI values of the parcels named as N0 (0kg N), N10 (10kg N), N20 (20kg N), 
$\mathrm{N} 30(30 \mathrm{~kg} \mathrm{~N}), \mathrm{N} 40(40 \mathrm{~kg} \mathrm{~N})$ and three replicates were evaluated by analysis of variance and the obtained analysis The results are given in Table 5.

When Table 5 is examined, it is observed that the The distribution of NDVI values obtained during the flowering period is statistically different between applications $(\mathrm{P}<0.01)$ and indifferent between repetitions (P> 0.05). It was found that the The distribution of

Table 5

Results of one-way variance analysis according to NDVI values between applications and recurrences

\begin{tabular}{|c|c|c|c|c|c|c|}
\hline $\begin{array}{l}\text { The period the images } \\
\text { were taken }\end{array}$ & Source of Variance & SS & DF & MS & F value & $\mathrm{P}$ value \\
\hline \multirow{4}{*}{ Before flowering } & Application & 0.03 & 4 & 0.007 & 2.231 & 0.155 \\
\hline & Recurrence & 0.006 & 2 & 0.003 & 0.829 & 0.471 \\
\hline & Error & 0.027 & 8 & 0.003 & & \\
\hline & Total & 0.062 & 14 & & & \\
\hline \multirow{4}{*}{ During flowering } & Application & 0.099 & 4 & 0.025 & 10.691 & $0.003 * *$ \\
\hline & Recurrence & 0.003 & 2 & 0.001 & 0.569 & 0.588 \\
\hline & Error & 0.019 & 8 & 0.002 & & \\
\hline & Total & 0.12 & 14 & & & \\
\hline \multirow{4}{*}{ After flowering } & Application & 0.048 & 4 & 0.012 & 1.542 & 0.279 \\
\hline & Recurrence & 0.002 & 2 & 0.001 & 0.140 & 0.871 \\
\hline & Error & 0.027 & 8 & 0.003 & & \\
\hline & Total & 0.113 & 14 & & & \\
\hline
\end{tabular}

$* * \mathrm{P}<0.01$

Table 6

The mean NDVI values according to the nitrogen dose applications on the parcel

\begin{tabular}{cccc}
\hline Applications & $\begin{array}{c}\text { Before } \\
\text { flowering } \\
\text { NDVI } \\
\text { values }\end{array}$ & $\begin{array}{c}\text { During } \\
\text { flowering } \\
\text { NDVI } \\
\text { values }\end{array}$ & $\begin{array}{c}\text { After } \\
\text { flowering } \\
\text { NDVI } \\
\text { values }\end{array}$ \\
\hline N0 (0kg N) & 0.825 & 0.713 & 0.769 \\
N10 (10kg N) & 0.872 & 0.846 & 0.859 \\
N20 (20kg N & 0.883 & 0.880 & 0.881 \\
N30(30kg N) & 0.937 & 0.935 & 0.936 \\
N40 (40kg N) & 0.945 & 0.932 & 0.939 \\
\hline
\end{tabular}

3.3. Relationship Between NDVI Values and Yield Values Obtained by Remote Sensing

Figure 6, Figure 7 and Figure 8 show the yield values measured during harvest in the field and the NDVI values calculated from the images taken images taken as remote sensing data before flowering, during flowering and after flowering over the land.
NDVI values obtained before and after flowering were statistically not different between the applications and repetitions at $5 \%$ significance level.

The mean NDVI values of the parcels of different nitrogen dose administration calculated from the images taken during all three periods of flowering before flowering and after flowering over the land are given in Table 6. 


\section{Yield-NDVI}

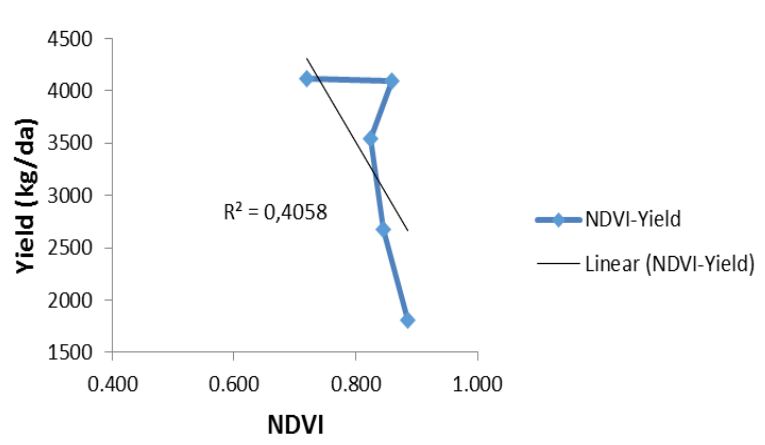

Figure 8

Relationship between NDVI values and yield after flowering

The equations 1, 2, and 3 of the graphs in Figure 6, Figure 7, and Figure 8, respectively, are given below.

$$
\begin{aligned}
& y=19,208 x-13894 \\
& y=10,651 x-5923,8 \\
& y=-9,9988 x+11515
\end{aligned}
$$

In the equations for the graphs in the figures, $y$ is the value of the equation, and $\mathrm{x}$ is the NDVI value. In order to know how high the relation between the two variables is, the determination coefficient $\left(R^{2}\right)$ values are calculated and expressed in the figures. It is understood that the relationship is high as the determination coefficient approaches 1 , and the relationship is low as it moves away from 1 .

As can be seen, the relationship between yield and NDVI values is very high $\left(\mathrm{R}^{2}=0.945\right)$ when images taken during the flowering period are used. This shows that the NDVI values calculated from the data obtained in the flowering period can be used to estimate the yield with high accuracy in the corn plant.

\section{Conclusions and Recommendations}

In this study, remote sensing images of silage corn plants planted in Selçuk Üniversitesi Sarıcalar Araştırma ve Uygulama Çiftliği in Konya were analyzed. Images from the land were taken using a special sensor camera capable of recording the near infrared, red and green wave lengths used in the remote sensing technique and the kite system. NDVI values were calculated by using these wave lengths on the images and the relationship between these values and the yield is determined. Thus the adequacy of these values were determined for use in yield estimation.

The plant height, number of cobs, height of cobs, stem diameter, leaf length, leaf width, plant weight, leaf weight, cob weight and stem weight were determined in the study. It has been investigated in which vegetative period of growing silage corn plant can be used to estimate the yield of remote sensing. It has been determined that the flowering period, which is the most prominent of the vegetative development, is the best time to take the remote sensing data. In the flowering period of the plant, the relationship between the yield and the NDVI values calculated from the remote sensing data was found to be very high $\left(\mathrm{R}^{2}=0.945\right)$.

In comparison with previous studies, Şimşek et al. (2007) found a relatonship between estimated yield values and observed yield values at $\mathrm{r}^{2}=0.9067$ in a study on wheat yield estimation and Unal and Aydoğdu (2012) found that the relation between biomass and TNDVI (Transformed Normalized Difference Vegetation Index) variables calculated by the Light Use Activity (LUE) model from satellite data is $r^{2}=0.69$ in studying the relationship between biomass and vegetation index.

The kite system used for taking images in this study is the cheapest system among the above picture taking systems. Because the system consists of kite, rope and picture taking system and it can be used repeatedly without any other expense (Üstüntaş and Bacaksız, 2010).

Open space is required for this system. The system can be used in the field. The picture-taking can be done in the open field with the appropriate wind. Pictures can be taken at times of 10-15 km / h wind speed depending on the weather conditions. Kite can not be removed under these values, it is difficult to control it below these values.

As a result of the study, a linear equation was established by using the relationship between NDVI values and yields of the flowering period in which the yieldNDVI relation is highest. This equation can be used for similar yield estimation studies due to the high correlation found.

Although yield prediction studies using this kind of low platform were not previously available for silage corn plants in this region, the data obtained in this study can be used in estimating yields using low or high remote sensing platforms. Such studies are important because of the increase in corn cultivation in the region and the fact that it is an important commercial plant due to the high importation of corn.

\section{Acknowledgements}

This study is summarized from the Master's Thesis of Nurettin KAYAHAN supported by BAP Coordinatorship of Selçuk University, Konya, Turkey (Project No. 11101022).

\section{References}

Ahmad MUD, Turral H, Nazeer A (2009). Diagnosing irrigation performance and water productivity through satellite remote sensing and secondary data in a large irrigation system of Pakistan. Agricultural Water Management, 96(4), 551-564.

Asher JB, Yosef BB, Volinsky R (2013). Ground-based remote sensing system for irrigation scheduling. Biosystems engineering, 114(4), 444-453.

Bernardes T, Moreira MA, Adami M, Giarolla A, Rudorff BFT (2012). Monitoring biennial bearing effect on 
coffee yield using MODIS remote sensing imagery. Remote Sensing, 4(9), 2492-2509.

Berni JA, Zarco-Tejada PJ, Suárez L, Fereres E (2009). Thermal and narrowband multispectral remote sensing for vegetation monitoring from an unmanned aerial vehicle. IEEE Transactions on Geoscience and Remote Sensing, 47(3), 722-738.Ibrikci 2012

Biradar CM, Thenkabail PS, Noojipady P, Li Y, Dheeravath V, Turral H, Xiao X (2009). A global map of rainfed cropland areas (GMRCA) at the end of last millennium using remote sensing. International journal of applied earth observation and geoinformation, 11(2), 114-129.

Bozkurt Y, Yazar A, Gençel B, Sezen MS (2006). Optimum lateral spacing for drip-irrigated corn in the Mediterranean Region of Turkey. Agricultural water management, 85(1-2), 113-120.

Deering DW (1978). Rangeland reflectance characteristics measured by aircraft and spacecraft sensors. Ph. D Dissertation. Texas A\&M Universtiy.

Delrue J, Bydekerke L, Eerens H, Gilliams S, Piccard I, Swinnen E (2013). Crop mapping in countries with small-scale farming: A case study for West Shewa, Ethiopia. International journal of remote sensing, 34(7), 2566-2582.

Fang H, Liang S, Hoogenboom G (2011). Integration of MODIS LAI and vegetation index products with the CSM-CERES-Maize model for corn yield estimation. International Journal of Remote Sensing, 32(4), 10391065.

Fang H, Liang S, Hoogenboom G, Teasdale J, Cavigelli M (2008). Corn-yield estimation through assimilation of remotely sensed data into the CSM-CERES-Maize model. International Journal of Remote Sensing, 29(10), 3011-3032.

Fritz S, Massart M, Savin I, Gallego J, Rembold F (2008). The use of MODIS data to derive acreage estimations for larger fields: A case study in the south-western Rostov region of Russia. International Journal of Applied Earth Observation and Geoinformation, 10(4), 453-466.

Gallego FJ, Kussul N, Skakun S, Kravchenko O, Shelestov A, Kussul O (2014). Efficiency assessment of using satellite data for crop area estimation in Ukraine. International Journal of Applied Earth Observation and Geoinformation, 29, 22-30.

Gholamhoseini M, AghaAlikhani M, Sanavy SM, Mirlatifi S M (2013). Interactions of irrigation, weed and nitrogen on corn yield, nitrogen use efficiency and nitrate leaching. Agricultural water management, 126, 9-18.

Guillén-Climent ML, Zarco-Tejada PJ, Villalobos FJ (2012). Estimating radiation interception in an olive orchard using physical models and multispectral airborne imagery. Israel Journal of Plant Sciences, 60(12), 107-121.

Hanbing Z, Xiaoping Y, Jialin L (2011). MODIS data based NDVI Seasonal dynamics in agro-ecosystems of south bank Hangzhouwan bay. African Journal of Agricultural Research, 6(17), 4025-4033.

Hatfield JL, Prueger JH (2010). Value of using different vegetative indices to quantify agricultural crop characteristics at different growth stages under varying management practices. Remote Sensing, 2(2), 562-578.
Hayes MJ, Decker WL (1996). Using NOAA AVHRR data to estimate maize production in the United States Corn Belt. Remote Sensing, 17(16), 3189-3200.

Herwitz SR, Johnson LF, Dunagan SE, Higgins RG, Sullivan DV, Zheng J, Slye RE (2004). Imaging from an unmanned aerial vehicle: agricultural surveillance and decision support. Computers and electronics in agriculture, 44(1), 49-61.

Ibrikci H, Ulger AC (2012). Assesment of corn (zea mays 1.) genotypes in relation to nitrogen fertilization under irrigated cropping conditions in Turkey.

Kogan F, Salazar L, Roytman L (2012). Forecasting crop production using satellite-based vegetation health indices in Kansas, USA. International journal of remote sensing, 33(9), 2798-2814.

Li Z, Chen Z (2011). Remote sensing indicators for crop growth monitoring at different scales. In Geoscience and Remote Sensing Symposium (IGARSS), 2011 IEEE International (pp. 4062-4065). IEEE.

Meroni M, Marinho E, Sghaier N, Verstrate MM, Leo O (2013). Remote sensing based yield estimation in a stochastic framework - Case study of durum wheat in Tunisia. Remote Sensing, 5(2), 539-557.

Prasad AK, Chai L, Singh RP, Kafatos M (2006). Crop yield estimation model for Iowa using remote sensing and surface parameters. International Journal of Applied Earth Observation and Geoinformation, 8(1), 2633.

Sakamoto T, Gitelson AA, Nguy-Robertson AL, Arkebauer TJ, Wardlow BD, Suyker AE, Shibayama M (2012). An alternative method using digital cameras for continuous monitoring of crop status. Agricultural and Forest Meteorology, 154, 113-126.

Sugiura R, Noguchi N, Ishii K (2005). Remote-sensing technology for vegetation monitoring using an unmanned helicopter. Biosystems engineering, 90(4), 369-379.

Şimşek O, Yıldız AMH, Özaydın KA, Çakmak B (2007). AgroMetShell modeli kullanılarak Türkiye'de buğdayın verim tahmini. TARIM BILIIMLERİ DERGİSI, 13(3), 299-307.

Tucker CJ, Holben BN, Elgin JJH, McMurtrey III JE (1980). Relationship of spectral data to grain yield variation. Photogrammetric Engineering and Remote Sensing, 46(5), 657-666.

Ulger AC, Ibrikci H, Cakir B, Guzel N (1997). Influence of nitrogen rates and row spacing on corn yield, protein content, and other plant parameters. Journal of plant nutrition, 20(12), 1697-1709.

Ünal E, Aydoğdu M (2012). Çankırı Meralarında Biyokütle ve Vejetasyon İndeks İlişkisi. Tarım Bilimleri Araştırma Dergisi, (2), 118-121.

Üstüntaş T, Bacaksız P (2010). Fotogrometride Küresel Yüzeyli Objelerin Resim Çekim Ve Değerlendirmesi Üzerine Deneysel Bir Uygulama, 5. Ulusal Mühendislik Ölçmeleri Sempozyumu, ZKÜ Merkez Kampusu Zonguldak.

Wu S, Huang J, Liu X, Fan J, Ma G, Zou J (2011). October). Assimilating MODIS-LAI into crop growth model with EnKF to predict regional crop yield. In International Conference on Computer and Computing Technologies in Agriculture (pp. 410-418). Springer, Berlin, Heidelberg. 